\title{
Designing a Problem-Based Mathematics Learning with the Integration of Guided Discovery Method
}

\author{
Nurhayati Abbas*, Perry Zakaria, Dwi Hardianty Djoyosuroto and Nurmala Ododay \\ Department of Mathematics, Faculty of Mathematics and Natural Sciences, Universities Negeri Gorontalo, 96128, \\ Indonesia \\ *Corresponding author. Email : Nurhayati_abbas@yahoo.co.id
}

\begin{abstract}
Two-variable linear equations topic is one of the mathematics learning topics for eighth graders (junior high level and its Islamic school equivalence or MTs). The topic is mostly associated with real-life problems, thereby requiring a specific teaching model. A model that is considered well-suited is problem-based learning with the integration of the guided discovery method. This teaching model can stimulate students in finding concepts, as well as investigating and solving problems, including higher-order thinking problems. Thus, it is essential to have instructional media in the form of active student and creative teacher-based lesson plans and student's worksheets. In consideration, the objective of the present study was to design a lesson plan and student's worksheet on the topic of two-variable linear equations by employing a problem-based learning model with the guided discovery method. The applied method was the 4-D model, i.e., define, design, develop, and disseminate, by Thiagarajan, Semmel, and Semmel (1974). However, this research only involved the first three stages. The result of expert validation suggested that the lesson plan and student's worksheet had been well-developed. Besides, the limited trial also showed that the students were actively involved during the lesson, with positive responses of both the students and teachers. On that ground, the design of the lesson plan and student's worksheet in the topic as mentioned above using a problem-based learning model with the guided discovery method is applicable in the learning process. This study recommends teachers to adopt this learning design and develop other learning designs for teaching similar topics.
\end{abstract}

\section{Keywords: Problem-based Learning, Guided Discovery Method, Instructional Design}

\section{INTRODUCTION}

Teachers require instructional media that depicts the concept of "active students" and "creative teachers". Nevertheless, several mathematics teachers tend to employ existing instructional media during teaching activities. Such media cannot encourage the students to study, as it is not developed by following students' characters.

Instructional media that bolster up learning management of the teachers are lesson plans and student's worksheets. A lesson plan is created based on a syllabus to guide teachers in the teaching and learning process [1]. It comprises faceto-face learning activity plans for one or more meetings. A lesson plan, which is developed from a syllabus, also directs students' learning activities to achieve basic competencies. A lesson plan is prepared upon basic competencies or sub-themes carried out in one or more meetings [2]. Accordingly, a lesson plan is designed by teachers for one-meeting activities that serve to help and direct them in managing the class.

On the other hand, a student's worksheet contains an assignment the students should work on. It is usually in the form of instructions and steps to accomplish the assignment. Also, the assignment instructed in the worksheet should define the basic competencies the students about to achieve. Such a worksheet is a guide for students to investigate and solve problems [3]. Therefore, a student's worksheet directs the students in learning, both in discovering concepts and solving problems.

Two-variable linear equations topic is one of the mathematics learning topics for eighth graders (junior high level and its Islamic school equivalence or MTs) that its 
content characterizes contextual problems [4]. Teaching this topic demands a model that can exercise students in formulating, investigating, and solving problems, as well as expressing and asking ideas. A model that is considered well-suited is the problem-based learning [5].

A problem-based learning model is a student learning approach to authentic (real) problems to construct their knowledge, grow and develop their skills to higher and inquiring capacity, be independent, and improve selfconfidence [6]. The problem-based teaching model's essence is presenting various authentic and meaningful problems to the students that can function as a milestone for investigation [7]. Simply put, a problem-based learning model characterizes a teaching process that presents authentic problems to students for them to solve through investigation. A teaching process that relies on the model mentioned earlier will develop one's ability to discover, investigate, and reveal ideas, so that it is worth applying for solving math problems. An investigation team can be formed voluntarily revolving around friendship patterns or according to particular social or cognitive arrangements [8]. For such reasons, a problem-based learning model can be integrated with a guided discovery method.

The method functions as mental processes where students can assimilate a concept or a principle. The mental processes encompass observing, absorbing, understanding, classifying, making assumptions, explaining, measuring, and drawing a conclusion [9]. A guided discovery method is one of the learning methods that require the students to find some ideas in the discovery process. In this process, the teacher guides them by giving oral or written instructions outlined in a student's worksheet [10]. Hence, this method is employed to train students to observe, absorb, understand, classify, make an assumption, explain, measure, and draw a conclusion in assimilating their knowledge to investigate and draw a conclusion. It is performed with minimal guidance from the teacher towards the investigated concept/principle.

A guided discovery method is a method to deliver mathematics topics to enable students to discover mathematical structures or patterns during the lesson through past experiences [11]. In this method, a concept to be learned is given in a guided manner and in a series of steps that can help them discover the concepts and solve problems with minimal assistance from the teacher.

A problem-based learning model integrated with the guided-discovery method is predictably able to enhance students' ability to investigate, solving problems, expressing ideas, asking questions, and discussing in mastering mathematics topics through teacher guidance as the facilitator. To teach two-variable linear equations, teachers should rely on a problem-based learning model with the integration of a guided discovery method that suits their students' characters. Lesson plans and student's worksheets as instructional media are also needed to develop.

Regarding the rationale, it is essential to develop a lesson plan and student's worksheet that refers to the syntax of the problem-based learning model with a guided discovery method, by which the students will get used to solving mathematical and higher-order thinking problems.

\section{METHODOLOGY}

This study was funded by Non-Tax State Revenues of Universities Negeri Gorontalo in 2020 that was carried out in two years. The first year was the development of instructional media; meanwhile, the second year was the implementation of the developed media. Moreover, this research was conducted in the Study Program of Mathematics Education and SMP 6 state junior high school in Gorontalo.

\subsection{Research Type and Design}

This is a development study that developed a lesson plan and student's worksheet through the following stages: introduction/establishment (define), planning (design), development (develop), and disseminating (disseminate) [12]. However, this research only involved the first three stages.

The define stage consisted of initial-final analysis, material analysis, formulation of competence achievement indicators, and formulation of learning objectives. Meanwhile, the design stage included the process of selecting the format and creating a lesson plan and student's worksheet. The last stage (develop) covered expert validation and empirical validation through a limited trial to gain information regarding students' activities, along with students' and teachers' responses.

\subsection{Data Collection Techniques}

The data were collected from a non-testing technique with a blank form as the instrument to gain the result of expert validation. A limited trial was then undertaken to get an overview of students' activities, students' responses, and teachers' responses during the problem-based learning with a guided discovery method that used a lesson plan and worksheet. Further, the data of students' activities during the learning process utilized an observation sheet with four-scale assessment, i.e., very active $=4$, active $=3$, quite active $=2$, less active $=1$. The assessment instrument of students' and teachers' responses used a checklist.

\subsection{Data Analysis Techniques}

The collected data were analyzed by employing descriptive and qualitative analysis. A descriptive analysis 
was used to describe the result of observation towards students' activities in the classroom in categories. The assessment category falls under poor $(0.00-1.69)$, fair $(1.70-2.59)$, good $(2.60-3.50)$, and excellent $(3.51-$ 4.00) categories [13]. In addition, the analysis of students' and teachers' responses utilized a percentage, which was then categorized. The assessment instrument of students' and teachers' responses used a checklist. On the contrary, a qualitative analysis was applied to interpret all input from experts written in the blank form.

\section{FINDINGS AND DISCUSSION}

The results and discussion refer to the lesson plan's development stages and student's worksheet, as proposed by Thiagarajan, Semmel, and Semmel, as follows.

\subsection{Define}

In this stage, the research team analyzed Curriculum 2013 (K-13) about core competencies and basic competencies [14]. Basic competencies that relate to knowledge and skills can be seen in Table 1 .

Table 1. Basic Competencies of Knowledge and Skills

\begin{tabular}{|c|c|}
\hline Basic Competencies & Basic Competencies \\
\hline $\begin{array}{ll}3.5 & \text { Explaining two- } \\
& \text { variable linear } \\
& \text { equations and their } \\
& \text { solutions related to } \\
& \text { contextual problems. }\end{array}$ & $\begin{array}{ll}4.5 & \text { Solving problems } \\
& \text { related to } \\
& \text { two-variable linear } \\
& \text { equations }\end{array}$ \\
\hline
\end{tabular}

Following the aforementioned basic competencies, the research team discussed with the teachers to obtain information regarding lesson hours to teach the basic competencies. The discussion with teachers in some state junior high schools, including SMP 1 State Junior High School in Suwawa Bone Bolango Regency, SMP 2 State Junior High School in Gorontalo Regency, SMP 3 State Junior High School in Gorontalo, and SMP 6 State Junior High School Gorontalo, showed that there were 15 and 18 lesson hours (excluding formative evaluation) related to basic competence 3.5 and 4.5 in Table 1. Both basic competencies comprise the topic of two-variable linear equations. Drew upon the discussion, it is approved to use 18 lesson hours, including formative evaluation.

Additionally, the result of two-variable linear material analysis consisted of elimination, substitution, and graphing methods. Each material contains a problem concept and solving. Mathematics lesson hours in junior high school and its Islamic school equivalence or MTs, based on the curriculum, were five hours per week; they were divided into two meetings, i.e., $2 \times 35$ minutes and 3 x 35 minutes. Next, it was also agreed to add one subtopic in two-variable linear equations, namely the use of combined elimination and substitution methods. All in all, there are four subtopics of two-variable linear equations, including elimination method, substitution method, combined methods of elimination and substitution, and graphing method.

The analysis result, as stated by the teachers, indicated that the students had the above-average ability. However, they had not undergone proper investigating, solving problems, expressing opinions, and asking questions. Additionally, the analysis result of basic competencies and subtopics obtained the formulation of competence achievement indicators and learning objectives, as presented in Table 2 .

Table 2. The Formulation of Competence Achievement Indicators and Learning Objectives

\begin{tabular}{lll}
\hline \multicolumn{1}{c}{ Competence Achievement Indicators } & & \multicolumn{1}{c}{ Learning Objectives } \\
\hline $3.1 .1 \quad \begin{array}{l}\text { Calculate the variable value of two- } \\
\text { variable linear equations using } \\
\text { elimination, substitution, the } \\
\text { combination of elimination and } \\
\text { substitution, and graphing method }\end{array}$ & 1. & $\begin{array}{l}\text { Correctly calculate the value of a variable in two-variable linear } \\
\text { equations using the elimination method. } \\
\text { Correctly calculate the value of a variable in two-variable linear } \\
\text { equations using the substitution method. }\end{array}$ \\
$\begin{array}{ll}\text { Correctly calculate the value of a variable in two-variable linear } \\
\text { equations using the combined elimination and substitution method. } \\
\text { Correctly calculate the value of a variable in two-variable linear }\end{array}$ \\
$\begin{array}{l}\text { Correctly solve the problem of two- } \\
\text { variable linear equations using } \\
\text { elimination, substitution, the } \\
\text { combination of elimination and } \\
\text { substitution, and graphing method. }\end{array}$ & 1. $\begin{array}{l}\text { Correctly solve the problem of two-variable linear equations using } \\
\text { the elimination method. }\end{array}$ \\
& 2. $\begin{array}{l}\text { Correctly solve the problem of two-variable linear equations using } \\
\text { the substitution method. } \\
\text { Correctly solve the problem of two-variable linear equations using } \\
\text { the combined method of elimination and substitution. } \\
\text { Correctly solve the problem of two-variable linear equations using } \\
\text { the graphing method. }\end{array}$ \\
\hline
\end{tabular}




\subsection{The Design Stage}

The lesson plan format is as follows: (a) institution name for school ID; (b) subjects identity; (c) class/semester; (d) subject matter; (e) time allocation; (f) basic competencies and indicators of competence achievement; (g) learning objectives; (h) instructional materials; (i) teaching methods; (j) learning media; (k) learning resources; (l) learning steps; and (m) assessment of learning outcomes [7]. Students' worksheet format is as follows: worksheet title; ID (student/group name, time allocation); learning objectives; measures of activity (a brief description of the material, example problems, and completion); evaluation regarding the theory.

The lesson plan preliminary draft is as follows: the method of elimination and substitution in the first meeting $(2 \times 35$ minutes), solving the two-variable linear equations problem using the method of elimination and substitution in the second meeting $(3 \times 35)$ in which the problem-solving steps will be instructed, the combined method of elimination and substitution in the third meeting ( $2 \times 35$ minutes), solving the two-variable linear equations problem using the combined method of elimination and substitution in the fourth meeting $(3 \times 35)$, the graphing method in the fifth meeting ( $2 \times 35$ minutes), solving the two-variable linear equations problem using the graphing method in the sixth meeting ( $3 \times 35$ minutes), and formative evaluation of twovariable linear equations in the seventh meeting $(2 \times 35$ minutes) or ( $3 \times 35$ minutes). The total lesson hours for the two-variable linear equations material and evaluation ranged between 17 - 18 hours of lessons with six items of the compiled lesson plan and students' worksheet.

\subsection{Stage of Development}

\subsubsection{Experts Validation Results}

Seven experts have validated the lesson plan and students' worksheets. Three mathematics teachers from junior high school and two mathematics lecturers validated the lesson plan and students' worksheets based on the mathematical content, while one lecturer validated the language, and another one validated the layout.

The overall results of expert validation for mathematic content and learning in the lesson plan and students' worksheet overall received a good assessment. However, it is recommended to provide problem-solving guidance at the beginning of its process, in which the students will be allowed to gradually solve the problem in groups or independently with the worksheets.

The validation results in terms of language and layout were considered good. Still, some sentences require corrections.

\subsubsection{The Field Test Results}

The field test activities were aimed to obtain information regarding the implementation of the lesson plan and student worksheet as a result of expert validation, which was held in a small class of student activities. In contrast, the response of students and teachers were implemented in two meetings.

a) The Students' Activity Analysis Results.

Aspects of students' activities that are measured encompassed: (1) listening/paying attention to the teacher's explanations (2) reading/observing the books/students' worksheet/problem, (3) working in groups to find the concept, (4) working together in groups to solve the problems, (5) writing activities that are relevant to learning, (6) discussing with/asking questions to student/group/teacher, (7) conveying ideas/opinions, (8) responding to teacher's/friends' questions, (9) presenting the results of the observation/practice/problem-solving/question, (10) reviewing the process of concept-finding/problemsolving/question, and (11) Summarizing the learning results of the day.

The data analysis results during the two meetings, with ten students obtained an average score of 3.50. This means that the students' average activeness during the learning process using a problem-based learning model with guided discovery method was considered in the active category. These findings indicate that almost all students are actively involved during the lesson, collaborate with the teacher and other students in the investigation, as well as having discussions. The collaboration of students in problem-based teaching encourages joint inquiry and dialogue and the development of thinking and social skills [3]. The same goes for the guided discovery method, which exposes students to a situation where they can investigate and draw conclusions. The guided discovery method encourages students to learn mostly from their own active involvement with particular concepts and principles [4]. A collaborative learning model using problem-based lea with the guided discovery method will instigate the students' active participation in learning.

b) Students' Response Analysis Results

Students' responses to the teaching process with the lesson plan and worksheet, that referred to the problem-based learning model with a guided discovery method, were measured based on the following aspects: (1) mood response in terms of the subject matter delivery, classroom learning activities, and teachers' method, (2) experience response in terms of the subject matter delivery, worksheets, classroom learning activities, and teachers' method, (3) helpfulness response in terms of worksheets and classroom learning activities, (4) opportunity response in terms of responding to the questions/opinions of the teacher or friends, and asking questions to the teacher or friends, (5) difficulty response in terms of 
responding to the questions/opinions of the teacher or friends, and asking questions to the teacher or friends; (6) interest response in terms of following the similar teaching model that was previously followed, (7) language response in worksheets and its layout (text, image, image position). The average analysis results of students' responses are provided in Table 3.

Table 3. Students' Average Response in Learning

\begin{tabular}{|c|c|c|}
\hline No & Responses & $\begin{array}{l}\text { Average } \\
\text { percentage } \\
\quad(\%)\end{array}$ \\
\hline 1 & $\begin{array}{l}\text { Pleased with the material delivery, } \\
\text { worksheets, classroom learning } \\
\text { activities, teachers' method }\end{array}$ & 100 \\
\hline 2 & $\begin{array}{l}\text { New to the material delivery, } \\
\text { worksheets, classroom learning } \\
\text { activities, teachers' method }\end{array}$ & 92.50 \\
\hline 3 & $\begin{array}{l}\text { "helpful" worksheets and classroom } \\
\text { learning activities }\end{array}$ & 100 \\
\hline 4 & $\begin{array}{l}\text { "Opportunities" to respond to } \\
\text { questions/opinions of the teacher or } \\
\text { friends, and asking questions to the } \\
\text { teacher or friends. }\end{array}$ & 85 \\
\hline 5 & $\begin{array}{l}\text { "Convenience" in responding to } \\
\text { questions/opinions of the teacher or } \\
\text { friends and asking questions to the } \\
\text { teacher or friends. }\end{array}$ & 60 \\
\hline 6 & $\begin{array}{l}\text { Interested in whether or not to follow } \\
\text { the similar teaching model that was } \\
\text { previously followed }\end{array}$ & 100 \\
\hline \multirow[t]{2}{*}{7} & $\begin{array}{l}\text { The language of worksheets and layout } \\
\text { were understandable }\end{array}$ & 100 \\
\hline & Average percentage & 91.07 \\
\hline
\end{tabular}

Table 3 shows that the average overall assessment of students' responses regarding a problem-based learning model with the guided discovery method obtained a very positive response $(91,07 \%)$. These findings revealed that teaching with said learning model had a positive response. Table 3 also elaborated the fact that the students' responses in terms of the ability to respond to teacher's and friends' questions or asking questions obtained a sufficient response (60\%), which means that the students found it relatively difficult to respond to the questions and opinions of the teacher and friends, or asking questions and opinions. This difficulty was due to the fact that the trial activities were only implemented in two meetings, whereas the students were not accustomed to asking questions or opinions to the teacher or friends and responding to it.

c) Teachers' Response Analysis Results

The teachers' responses to the teaching process with the lesson plan and worksheet, which referred to the problem-based model with a guided discovery method, were measured based on the following aspects: (1) the helpfulness of the lesson plan and worksheet examples in the learning process, (2) the assessment of the lesson plan and worksheet, (3) a necessary and proper learning model to be developed in other materials, (4) the activities that need to be done (if requires development).

The response assessment results of two mathematics teachers from SMP 6 state junior high school in Gorontalo indicated that the lesson plan and worksheet, which refers to the problem-based model with the guided discovery method, were considered very good and helpful in the learning activities. The said model needs to be developed for other materials and requires training. This means that teachers also provide a positive response to the lesson plan and worksheets developed by the research team.

All in all, the students and teachers respond positively to the lesson plan and worksheets developed by the research team. There is a great amount of enthusiasm among teachers and students regarding the problembased learning model [15].

Based on the validation experts' results and the limited trial in small groups on the implementation of a problem-based learning model with the guided discovery method showed the students activeness during the lesson and very positive responses from the students and teachers.

\section{CONCLUSION}

Based on the findings and discussion, it can be concluded that the lesson plan and worksheet, which refer to the problem-based learning model with the guided discovery method, are considered feasible to be used as one of the alternative learning examples for the topic of two-variable linear equations and other mathematics topics with similar characteristics.

\section{ACKNOWLEDGMENT}

The research team send our gratitude to the Rector of Universities Negeri Gorontalo, who had provided the nontax revenues research funding, along with the Transbahasa Team for translating this article. We also thank the Head of Education and Culture Department of Gorontalo City, the Principle of SMP 6 state junior high school in Gorontalo, colleague of lecturers, and mathematic teachers who helped the research activities. Hopefully, this collaboration will be continued.

\section{REFERENCES}

[1] F. Spooner, J. N. Baker, A. A. Harris, L. AhlgrimDelzell, D. M. Browder. Effects of training in universal design for learning on lesson plan development .Remedial and special education, 28 (2) (2007) 108116. DOI: https://doi.org/10.1177/07419325070280020 101 
[2] A. Nygårdh, D. Malm, K. Wikby, G. Ahlström. The experience of empowerment in the patient-staff encounter: the patient's perspective. Journal of clinical nursing, 21 (5-6) (2012) 897-904. DOI: https://doi.org/ 10.1111/j.1365-2702.2011.03901.x

[3] C. E. Hmelo-Silver, R. G. Duncan, C. A. Chinn. Scaffolding and achievement in problem-based and inquiry learning: a response to Kirschner, Sweller, and. Educational psychologist, 42 (2) (2007) 99-107. DOI: https://doi.org/10.1080/00461520701263368

[4] J. Cai, B. Nie, J. C. Moyer. The teaching of equation solving: Approaches in Standards-based and traditional curricula in the United States. Pedagogies: An International Journal, 5 (3) (2010) 170-186. DOI: https://doi.org/10.1080/1554480X.2010.485724

[5] E. Pawson, E. Fournier, M. Haigh, O. Muniz, J. Trafford, S. Vajoczki. Problem-based learning in geography: Towards a critical assessment of its purposes, benefits and risks. Journal of Geography in Higher Education, 30 (1) (2006) 103-116. DOI: https://doi.org/10.1080/03098260500499709

[6] K. N. L. Wee. A problem-based learning approach in entrepreneurship education: promoting authentic entrepreneurial learning. International Journal of Technology Management, 28 (7-8) (2004) 685-701. DOI: https://doi.org/10.1504/IJTM.2004.005777

[7] J. J. Watters, I. S. Ginns. Developing motivation to teach elementary science: Effect of collaborative and authentic learning practices in preservice education . Journal of Science Teacher Education, 11 (4) (2000) 301-321. DOI: https://doi.org/10.1023/A:10094291310 64

[8] M. E. Gifford-Smith, C. A. Brownell. Childhood peer relationships: Social acceptance, friendships, and peer networks. Journal of school psychology, 41 (4) (2003) 235-284. DOI: https://doi.org/10.1016/S0022-4 405(03)00048-7

[9] G. Cerulli. Modelling and measuring the effect of public subsidies on business R\&D: a critical review of the econometric literature. Economic Record, 86 (274) (2010) 421-449. DOI: https://doi.org/10.1111/j.14754932.2009.00615.x

[10] S. Suhono, D. A. Sari. Developing Students' Worksheet Based Educational Comic for Eleventh Grade of Vocational High School Agriculture . Anglophile Journal, 1 (1) (2020) 29-40. DOI: http:// dx.doi.org/10.51278/anglophile.v1i1.78
[11] L. Benton, P. Saunders, I. Kalas, C. Hoyles, R. Noss. Designing for learning mathematics through programming: A case study of pupils engaging with place value. International journal of child-computer interaction, 16 (2018) 68-76. DOI: https://doi.org/10.10 16/j.ijcci.2017.12.004

[12] R. H. Ristanto, S. Zubaidah, M. Amin, F. Rohman. From a reader to a scientist: developing cirgi learning to empower scientific literacy and mastery of biology concept. Biosfer: Jurnal Pendidikan Biologi, 11 (2) (2018) 90-100. DOI: https://doi.org/10.21009/biosferjp b.v11n2.90-100

[13] A. M. Ferrari, L. Volpi, M. Pini, C. Siligardi, F. E. García-Muiña, D. Settembre-Blundo. Building a sustainability benchmarking framework of ceramic tiles based on life cycle sustainability assessment (LCSA). Resources, 8 (1) (2019) 11. DOI: https://doi. org/10.3390/resources8010011

[14] I. Gunawan. Instructional management in indonesia: a case study. Researchers World, 8 (1) (2017) 99. DOI: 10.18843/rwjasc/v8i1/12

[15] R. Ramadhani, U. M. A. M. Rofiqul, A. Abdurrahman, M. SYAZALI. The effect of flippedproblem based learning model integrated with LMSgoogle classroom for senior high school students. Journal for the Education of Gifted Young Scientists, 7 (2) (2019) 137-158. DOI: https://doi.org/1 $0.17478 /$ jegys. 548350 